\title{
Development and physicochemical evaluation of pharmacosomes of diclofenac
}

\author{
AJAY SEMALTY ${ }^{1 *}$ \\ MONA SEMALTY ${ }^{1}$ \\ DEVENDRA SINGH ${ }^{2}$ \\ M. S. M. RAWAT ${ }^{2}$ \\ ${ }^{1}$ Department of Pharmaceutical Sciences \\ H. N. B. Garhwal University, Srinagar \\ Garhwal, India \\ 2 Department of Chemistry, H. N. B. \\ Garhwal University, Srinagar Garhwal \\ India
}

\begin{abstract}
Pharmacosomes are amphiphilic lipid vesicular systems that have shown their potential in improving the bioavailability of poorly water soluble as well as poorly lipophilic drugs. Diclofenac is a poorly water soluble drug and also causes gastrointestinal toxicity. To improve the water solublity of diclofenac, its pharmacosomes (phospholipid complex) have been prepared and evaluated for physicochemical analysis. Diclofenac was complexed with phosphatidylcholine ( $80 \%)$ in equimolar ratio, in the presence of dichloromethane, by the conventional solvent evaporation technique. Pharmacosomes thus prepared were evaluated for drug solubility, drug content, surface morphology (by scanning electron microscopy), phase transition behaviour (by differential scanning calorimetry), crystallinity (by X-ray powder diffraction) and in vitro dissolution. Pharmacosomes of diclofenac were found to be irregular or disc shaped with rough surfaces in SEM. Drug content was found to be $96.2 \pm 1.1 \%$. DSC thermograms and XRPD data confirmed the formation of the phospholipid complex. Water solubility of the prepared complex was found to be $22.1 \mu \mathrm{g} \mathrm{mL}^{-1}$ as compared to $10.5 \mu \mathrm{g} \mathrm{mL}^{-1}$ of diclofenac. This improvement in water solubility in prepared pharmacosomes may result in improved dissolution and lower gastrointestinal toxicity. Pharmacosomes showed $87.8 \%$ while the free diclofenac acid showed a total of only $60.4 \%$ drug release at the end of $10 \mathrm{~h}$ of dissolution study.
\end{abstract}

Keywords: diclofenac, solubility, pharmacosomes, phospholipid complex

Diclofenac is one of the most widely prescribed non-steroidal anti-inflammatory drugs (NSAIDs). Use of diclofenac is associated with two major limitations; first, rare, but serious and sometimes fatal, gastrointestinal (GI) side-effects, including ulceration, and hemorrhage, especially in the elderly $(1,2)$, and second, poor water solubility.

\footnotetext{
* Correspondence; e-mail: semaltyajay@yahoo.co.in
} 
Different approaches have been applied to decrease NSAID-induced GI toxicity. For example, association of NSAIDs with phospholipids has been suggested to improve GI safety of these drugs (3). The presence of an adsorbed layer of surface-active phospholipids on the surface of the mucus that covers the surface epithelium is suggested to protect the GI tissues by providing a hydrophobic layer between the epithelium and the luminal contents $(4,5)$. It has been reported that NSAIDs associated with zwitterionic phospholipids may reduce GI toxicity (3).

Besides GI toxicity of diclofenac, it is also poorly water soluble, due to which its dissolution in GI fluid is very low, which in turn adversely affects the bioavailability (50-60 $\%$ only). The association of diclofenac with zwitterionic phospholipids, which may be both electrostatic and hydrophobic in nature, renders the phospholipids more water-soluble and the NSAID more lipid-soluble (6). It has been reported that the diffusion of NSAIDs across lipid membranes and into target cells is accelerated when they are in a complex with phosphatidylcholine (PC) (3).

Therefore developing drugs as lipid complexes (pharmacosomes) may be a potential approach to improve solubility and to minimize the GI toxicity of diclofenac. Pharmacosomes are amphiphilic drug-lipid complexes, which are stable and more bioavailable drug delivery systems with low interfacial tension between the system and the GI fluid, thereby facilitating the membrane, tissue, or cell wall transfer in the organism (7).

This work aims to develop and characterize the pharmacosomes of diclofenac along with its in vitro drug release study.

\section{EXPERIMENTAL}

\section{Materials}

Diclofenac potassium was obtained as a gift sample from Wings Pharma, India. Soya phosphatidylcholine (LIPOID S-80) was obtained as a gift sample from LIPOID, Germany. All other chemicals were of analytical grade.

\section{Formulation of pharmacosomes}

Diclofenac salt was converted into the acid form to provide an active hydrogen site for complexation. Diclofenac acid was prepared by acidification of an aqueous solution of diclofenac potassium, extraction into chloroform, and subsequent recrystallization. Diclofenac-PC complex was prepared by associating diclofenac acid with an equimolar concentration of PC. The equimolar concentration of PC and diclofenac acid were placed in a 100-mL round bottom flask and dissolved in dichloromethane. The solvent was evaporated under vacuum at $40{ }^{\circ} \mathrm{C}$ in a rotary vacuum evaporator (Perfit Model No. 5600, Büchi type, Perfit Ltd., India). The pharmacosomes were collected as the dried residue and placed in a vacuum desiccator overnight and then subjected to characterization. 


\section{Drug content}

To determine the drug content in pharmacosomes of diclofenac (diclofenac-PC complex), a complex equivalent to $50 \mathrm{mg}$ diclofenac was weighed and added into a volumetric flask with $100 \mathrm{~mL}$ of $\mathrm{pH} 6.8$ phosphate buffer. Then the volumetric flask was stirred continuously for $24 \mathrm{~h}$ on a magnetic stirrer. At the end of $24 \mathrm{~h}$, suitable dilutions were made and measured for the drug content at $276 \mathrm{~nm}$ UV spectrophotometrically (double beam UV-Visible spectrophotometer, Lambda 25, Perkin Elmer, USA).

\section{Solubility}

To determine the change in solubility due to complexation, solubility of diclofenac acid and diclofenac-PC complex was determined in $\mathrm{pH} 6.8$ phosphate buffer and $n$-octanol by the shake-flask method. Diclofenac acid $(50 \mathrm{mg}$ ) (and $50 \mathrm{mg}$ equivalent in case of complex) was placed in a 100-mL conical flask. Phosphate buffer $\mathrm{pH} 6.8(50 \mathrm{~mL})$ was added and then stirred for 15 minutes. The suspension was then transferred to a $250 \mathrm{~mL}$ separating funnel with $50 \mathrm{~mL} n$-octanol and was shaken well for 30 minutes. Then the separating funnel was kept still for about 30 minutes. Concentration of the drug was determined from the aqueous layer spectrophotometrically at $276 \mathrm{~nm}$.

\section{Scanning electron microscopy (SEM)}

To detect the surface morphology of the pharmacosomes, SEM of the complex was recorded on a scanning electron microscope (JEOL JSM 5600, Japan).

\section{Differential scanning calorimetry (DSC)}

Thermograms of diclofenac acid, phosphatidylcholine $(80 \%)$ and the diclofenac-PC complex were recorded using a 2910 Modulated Differential Scanning Calorimeter V4.4E (TA Instruments, USA). The thermal behavior was studied by heating $2.0 \pm 0.2 \mathrm{mg}$ of each individual sample in a covered sample pan under nitrogen gas flow. The investigations were carried out over the temperature range $25-250{ }^{\circ} \mathrm{C}$ at a heating rate of $10^{\circ} \mathrm{C} \mathrm{m^{-1 }}$.

\section{X-ray powder diffraction (XRPD)}

The crystalline state of diclofenac in the different samples was evaluated using X-ray powder diffraction. Diffraction patterns were obtained on a Bruker Axs- D8 Discover Powder X-ray diffractometer, Germany. The X-ray generator was operated at 40 $\mathrm{kV}$ tube voltages and $40 \mathrm{~mA}$ tube current, using the $\mathrm{K} \alpha$ lines of copper as the radiation source. The scanning angle ranged from 1 to $60^{\circ}$ of $2 \theta$ in the step scan mode (step width $0.4^{\circ} \mathrm{min}^{-1}$ ). Diclofenac acid, phosphatidylcholine $80 \%$ (Lipoid S-80) and the prepared complex were analyzed. The results are shown in Fig. 3. 


\section{Dissolution study}

In vitro dissolution studies of diclofenac complex as well as plain diclofenac acid were performed in triplicate in a USP (8) six station dissolution test apparatus, type II (Veego Model No. 6 DR, India) at $100 \mathrm{rpm}$ and at $37^{\circ} \mathrm{C}$. An accurately weighed amount of the complex equivalent to $100 \mathrm{mg}$ of diclofenac acid was put into $900 \mathrm{~mL}$ of $\mathrm{pH} 6.8$ phosphate buffer. Samples ( $3 \mathrm{~mL}$ each) of dissolution fluid were withdrawn at different intervals and replaced with an equal volume of fresh medium to maintain sink conditions. Withdrawn samples were filtered (through a $0.45-\mu \mathrm{m}$ membrane filter), diluted suitably and then analyzed spectrophotometrically at $276 \mathrm{~nm}$. Fig. 4 gives a graphical representation of the in vitro release profile from the formulations.

\section{Statistical analysis}

Results are expressed as mean values \pm standard deviations and the significance of the difference observed was analyzed by Student's $t$-test.

\section{RESULTS AND DISCUSSION}

Pharmacosomes of diclofenac were prepared with an equimolar ratio (1:1) of diclofenac and phopsphatidylcholine in the presence of dichloromethane by the conventional solvent evaporation technique. The content of diclofenac in the pharmacosome, as estimated by UV spectrophotometry, was found to be $96.2 \pm 1.1 \%(\mathrm{~m} / \mathrm{m})$. Pharmacosomes showed a high percentage of drug loading, which is specific to them. Complexation provides good percent loading of the drug, which makes the drug delivery clinically feasible. On the other hand, in liposomes of diclofenac sodium, the encapsulation efficiency was found to be just $59 \%$ (9). Special methods such as coating of these vesicular systems were needed to improve the loading of the drug. This is not required in the pharmacosomes in which the drug is reversibly bonded chemically with the lipids and thus shows not only good percent loading but also better stability than in liposomes.

Water solubility of diclofenac from pharmacosomes was found to be much higher than that of diclofenac acid. Table I provides the solubility data. The increase in solubility of diclofenac acid in the complex can be explained by the fact that solubilization resulted from the micelle formation in the medium and by the amorphous characteristics of the complex. As amphiphilic surfactants, phospholipids could increase the solubility

Table I. Solubility study of diclofenac acid and its pharmacosomes

\begin{tabular}{ccc}
\hline \multirow{2}{*}{ Drug } & \multicolumn{2}{c}{ Solubility } \\
\cline { 2 - 3 } & Aqueous layer $\left(\mu \mathrm{g} \mathrm{mL} \mathrm{mL}^{-1}\right)^{\mathrm{a}}$ & $n$-Octanol layer $\left(\mu \mathrm{g} \mathrm{mL}{ }^{-1}\right)^{\mathrm{a}}$ \\
\hline Diclofenac acid & $10.5 \pm 1.5$ & $30.5 \pm 1.0$ \\
Diclofenac pharmacosomes & $22.1 \pm 2.4$ & $32.5 \pm 1.4$ \\
\hline
\end{tabular}

a Mean $\pm \mathrm{SD} ; n=3$. 

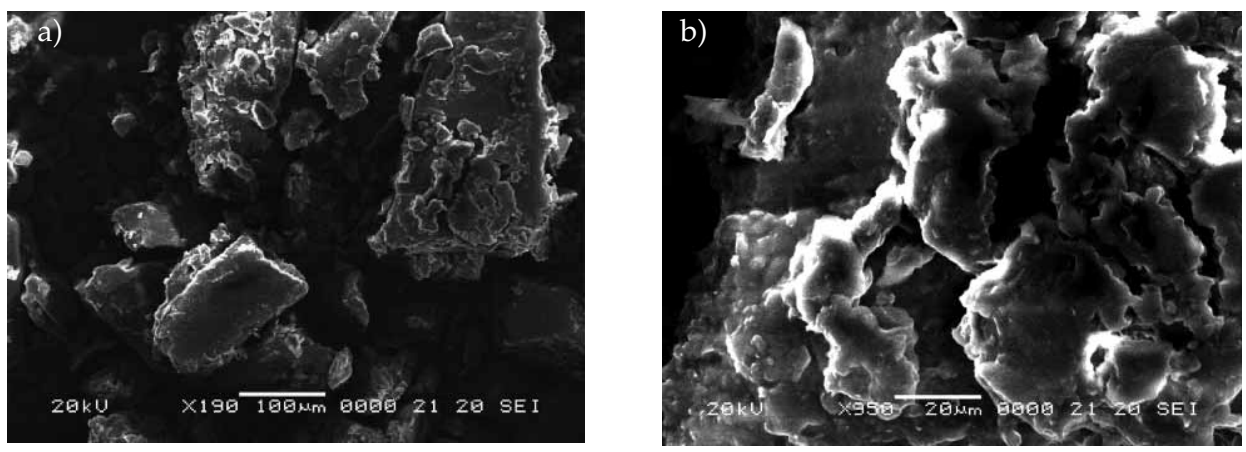

Fig. 1. SEM of pharmacosomes of diclofenac: a) 190X magnification, b) 950X magnification.

of the drug by the action of wetting and dispersion $(3,6)$. Unlike the non-polar nature of diclofenac, the complex showed amphiphilic nature, which may prove to be responsible for improved bioavailability of the drug (10).

Scanning electron micrographs of the complex are shown in Fig. 1. Pharmacosomes were found to be irregular or disc shaped with rough surface morphology. The complex was found to involve free flowing particles. Phospholipids are natural components, so their different purity grades may have different effects on the shape and surface morphology (11).

In order to substantiate the association of diclofenac acid with PC, DSC analysis was performed on diclofenac acid, PC, and the pharmacosomes of diclofenac. Results confirmed the association of diclofenac acid and PC in the complex as both peaks representing diclofenac acid and PC changed positions. Phospholipids (Fig. 2b) showed two major peaks at $83.21{ }^{\circ} \mathrm{C}$ and $107.90^{\circ} \mathrm{C}$ and a small peak at $64.45^{\circ} \mathrm{C}$. The first peak of phospholipids is a mild peak (at $64.45^{\circ} \mathrm{C}$ ), which is probably due to the hot movement of the phospholipid polar head group. The second $\left(83.21^{\circ} \mathrm{C}\right)$ peak is very sharp, which appears to be due to the phase transition from gel to liquid crystalline state. The non-polar hydrocarbon tail of phospholipids may be melted during this phase, yielding a sharp peak. This melting might have occurred in two phases that subsequently gave another peak $\left(107.90{ }^{\circ} \mathrm{C}\right)$, which is relatively less sharp. Diclofenac acid (Fig. 2a) showed a sharp endothermic peak at $171.31{ }^{\circ} \mathrm{C}$. On the other hand, pharmacosomes of diclofenac (Fig. 2c) showed a broad peak at $68.34^{\circ} \mathrm{C}$, which is different from the peaks of the individual components of the complex. It is evident that the original peaks of diclofenac and phospholipids disappear from the thermogram of pharmacosomes (complex) and the phase transition temperature is lower than that of phospholipids. The DSC thermograms of the phospholipid complexes of some phytoconstituents, like silybin, puerarin, curcumin and some xanthones, revealed similar results (12-14).

To check whether the changes in the diclofenac crystal morphology correspond to a polymorphic transition and to study the solid state of diclofenac phospholipid complex, XRPD analysis was conducted. The XRPD of diclofenac complex revealed a broad peak similar to PC (Fig. 3). It suggested that the diclofenac in the phospholipid complex was either in amorphous form or molecularly dispersed. These results are well supported by 

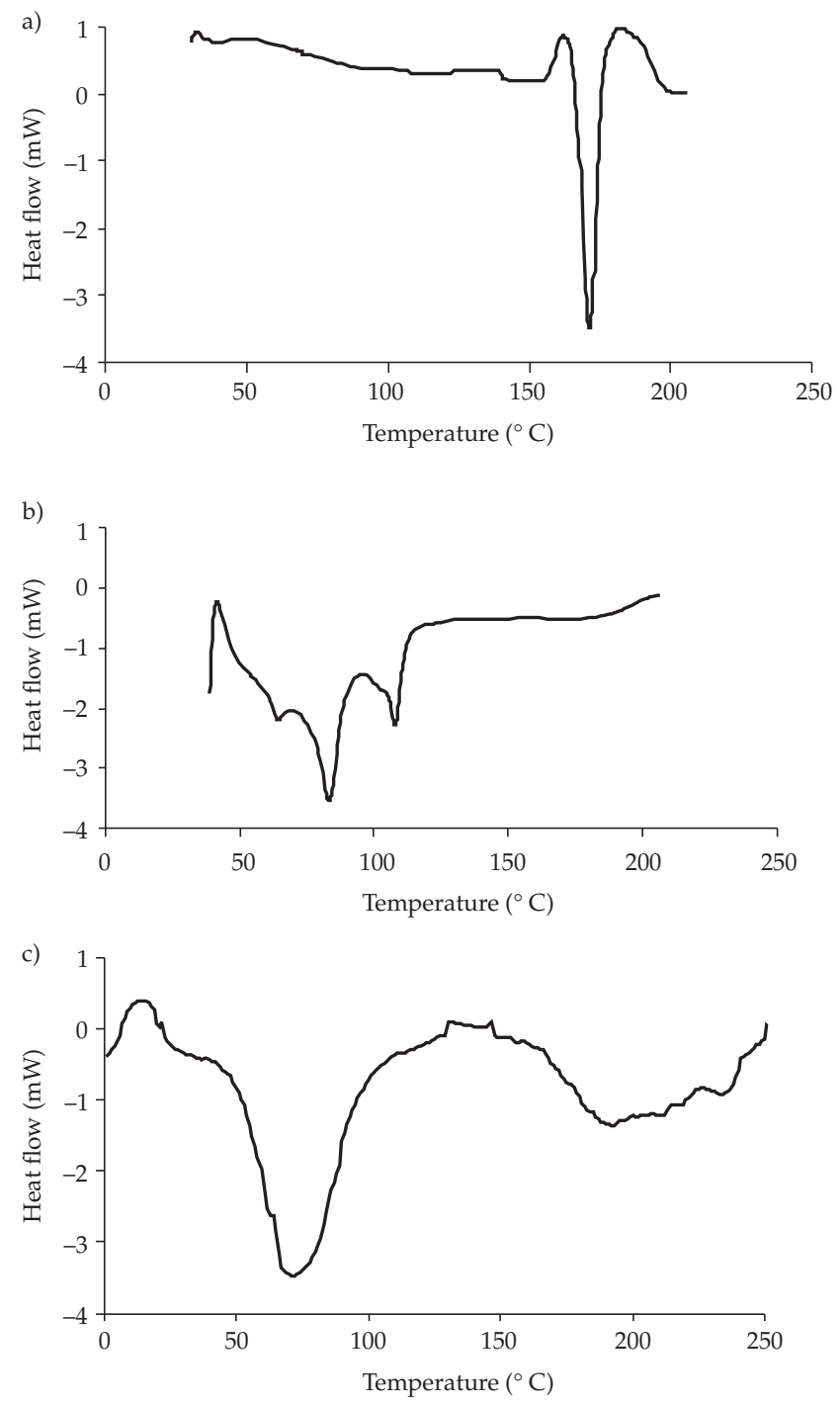

Fig. 2. DSC thermograms of: a) diclofenac acid, b) phosphatidylcholine, and c) pharmacosome of diclofenac.

our previous studies done with the phospholipid complexes of aspirin (11). The disappearance of diclofenac crystalline diffraction peaks confirmed the formation of the phospholipid complex. Unlike liposomes, chemical bonding between the drug and phospholipids in the development of pharmacosomes might have resulted into a significant change of its X-ray diffraction. 


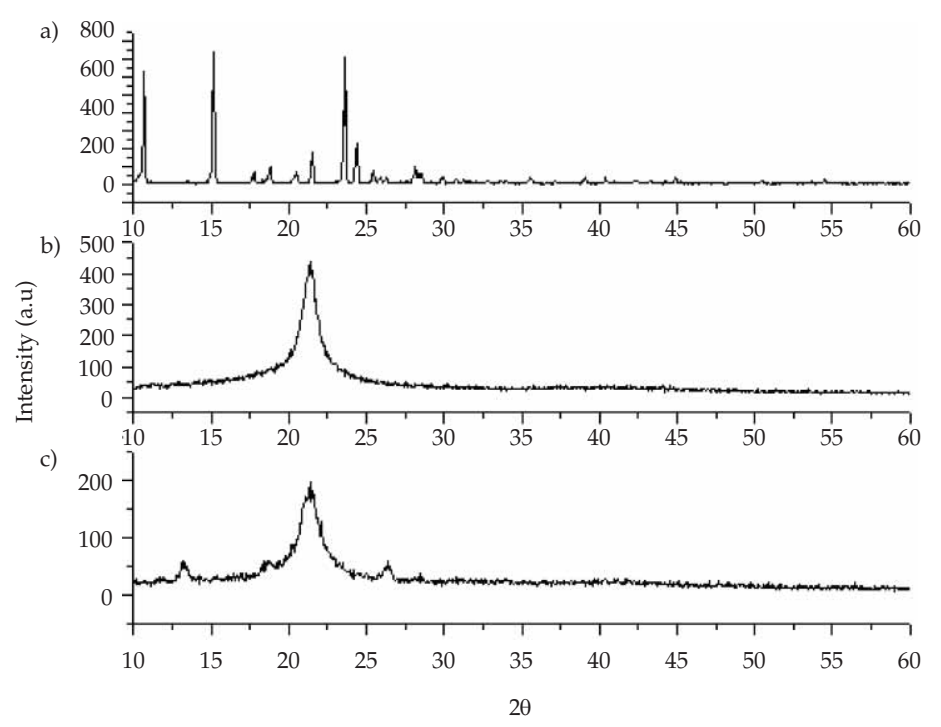

Fig. 3. X-ray powder diffraction (XRPD) study of: a) diclofenac acid, b) phosphatidylcholine and c) pharmacosome of diclofenac.

The pharmacosomes of diclofenac showed a better dissolution profile than diclofenac acid (Fig. 4). Unlike free diclofenac acid (which showed only $60.4 \%$ drug release at the end of $10 \mathrm{~h}$ ) the diclofenac complex showed $87.8 \%$ at the end of $10 \mathrm{~h}$ of the dissolution study in $\mathrm{pH} 6.8$ phosphate buffer. Solid dissolution is a complex operation influ-

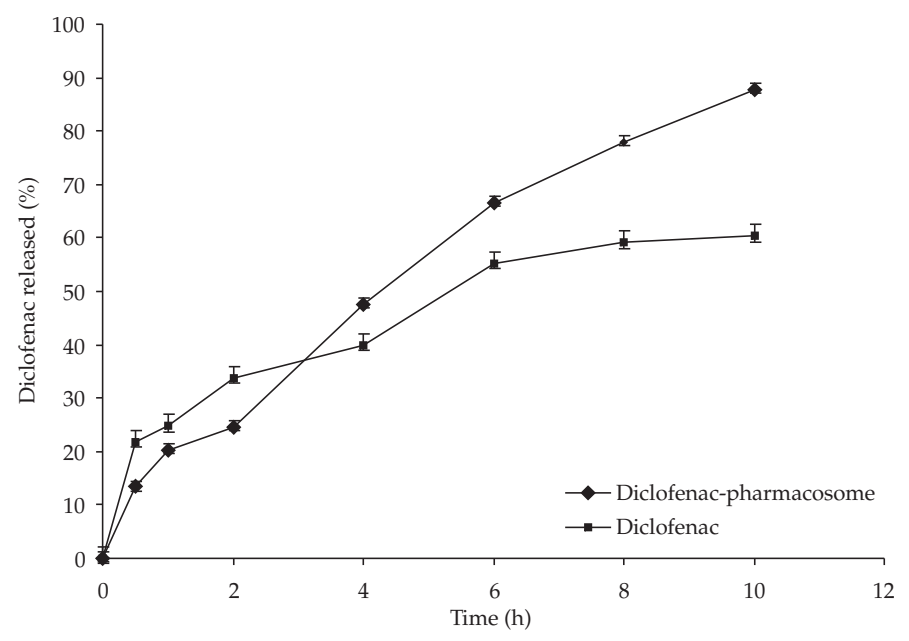

Fig. 4. Dissolution study of pharmacosomes of diclofenac and diclofenac acid (mean $\pm \mathrm{SD} ; n=3$ ). 
enced by a number of factors, not only by particle size. Differences in the crystal habit, surface area, surface energies, particle size and wettability may all play a role in affecting the dissolution rate of powder (15). Phospholipids being amphiphilic surfactants, increased the solubility of the drug by the action of wetting and dispersion. That is why the dissolution profile of the complex was found to be improved. In some studies done with silybin and xanthones, the in vitro drug release from the complexes was found to be $\mathrm{pH}$ dependent and with the increase of the medium $\mathrm{pH}$ the drug dissolution was increased (12).

\section{CONCLUSIONS}

In the present study, a diclofenac-phospholipid complex (pharmacosomes) was prepared by a simple and reproducible method and evaluated for various physicochemical parameters. Physicochemical investigations showed that diclofenac formed a stoichiometric complex with phospholipid with improved solubility and dissolution profile. DSC and XRPD studies confirmed the formation of the complex. Thus it can be concluded that the pharmacosomes of diclofenac may be of potential use for improving dissolution and for reducing the gastrointestinal toxicity of the drug.

Pharmacosomes may be developed also for other NSAIDs with poor bioavailability and GI side effects. Moreover, the pharmacosomes of phytoconstituents (with poor water and/or lipid solubility) may also be developed for improving their aqueous solubility and lipophilicity and hence bioavailability.

Acknowledgements. - The authors are thankful for the DST Research grant (SRSO/HS/ 72/2006). The authors acknowledge LIPOID GmbH Germany for providing the gift sample of phosphatidylcholine for the research work. Facilities provided by the UGC-DAE Consortium for Scientific Research, Indore (India), are gratefully acknowledged.

\section{REFERENCES}

1. P. M. Peloso, Strategies and practice for the use of nonsteroidal anti-inflammatory drugs, Scan. J. Rheumatol. 25 (1996) 29-48.

2. A. Figueras, D. Capella, J. M. Castel and J. R. Laporte, Spontaneous reporting of adverse drug reactions to nonsteroidal anti-inflammatory drugs, Eur. J. Clin. Pharmacol. 47 (1994) 297-303; DOI: $10.1007 /$ BF00191158.

3. L. M. Lichtenberger, Z. M. Wang, J. J. Romero, C. Ulloa, J. C. Perez, M. N. Giraud and J. C. Barreto, Non steroidal anti-inflammatory drugs (NSAIDs) associate with zwitterionic phospholipids: Insight into the mechanism and reversal of NSAID-induced gastrointestinal injury, Nature Med. 11 (1995) 154-158; DOI: 10.1038/nm0295-154.

4. P. J. Goddard, Y. J. Kao and L. M. Lichtenberger, Luminal surface hydrophobicity of canine gastric mucosa is dependent on a surface mucous gel, Gastroenterology 98 (1990) 361-370.

5. L. M. Lichtenberger, L. A. Graziani, E. J. Dial, B. D. Butter and B. A. Hills, Role of surface-active phospholipids in gastric cytoprotection, Science 219 (1983) 1327-1329; DOI: 10.1126/science.6828 859. 
6. L. M. Lichtenberger, C. Ulloa, J. J. Romero, A. L. Vanous, J. J. Romero, E. J. Dial, P. A. Illich and E. T. Walters, Zwitterionic phospholipids enhance aspirin's therapeutic activity, as demonstrated in rodent model systems, J. Pharmacol. Exp. Ther. 277 (1996) 1221-1227.

7. S. S. Biju, S. Talegaonkar, P. R. Mishra and R. K. Khar, Vesicular systems: an overview, Indian J. Pharm. Sci. 68 (2006) 141-153.

8. United States Pharmacopoeia 23, National Formulary 18, USP Convention, Rockville (MD) 1999, pp. 1791-1792.

9. H. Maswadeh, A. Abdulhalim and C. Demetzos, Improvement of encapsulation efficiency of diclofenac sodium into uncoated and chitosan-coated liposomes, Indian J. Pharm. Sci. 66 (2004) 607-612.

10. L. M. Lichtenberger, C. Ulloa, J. J. Romero, A. L. Vanous, P. A. Illich and E. J. Dial, Nonsteroidal anti-inflammatory drug and phospholipid prodrugs: Combination therapy with antisecretory agents in rats, Gastroenterology 111 (1996) 990-995; DOI: 10.1016/S0016-5085(96)70066-5.

11. M. Semalty, A. Semalty, D. Singh, T. Chamoli and M. S. M. Rawat, Effect of purity of phospholipids in improving bioavailability performance of aspirin-phospholipid complex, National Convention of Chemistry Teachers (NCCT) Annual Conference and Convention, Nov 8-9 2008, Srinagar (Garhwal), India, Book of Abstracts, Indian Association of Chemistry Teachers, Srinagar 2008, p. 72.

12. X. Yanyu, S. Yunmei, C. Zhipeng and P. Quineng, The preparation of silybin-phospholipid complex and the study on its pharmacokinetics in rats, Int. J. Pharm. 307 (2006) 77-82; DOI: 10.1016/ j.ijpharm.2005.10.001.

13. Y. Li, D. J. Yang, S. L. Chen, S. B. Chen and A. S. C. Chan, Comparative physicochemical characterization of phospholipids complex of puerarin formulated by conventional and supercritical methods, Pharm. Res. 25 (2007) 563-577; DOI: 10.1007/s11095-007-9418-x.

14. K. Maiti, K. Mukherjee, A. Gantait, B. P. Saha and P. K. Mukherjee, Curcumin-phospholipid complex: Preparation, therapeutic evaluation and pharmacokinetic study in rats, Int. J. Pharm. 330 (2007) 155-163; DOI: 10.1016/j.ijpharm.2006.09.025.

15. D. J. Jarmer, C. S. Lengsfeld, K. S. Anseth and T. W. Randolph, Supercritical fluid crystallization of griseofulvin: Crystal habit modification with a selective growth inhibitor, J. Pharm. Sci. 94 (2005) 2688-2702; DOI: 10.1002/jps.20463.

\section{Razvoj i fizikokemijsko vrednovanje farmakosoma diklofenaka}

AJAY SEMALTY, MONA SEMALTY, DEVENDRA SINGH i M. S. M. RAWAT

Farmakosomi su amfifilni lipidni vezikularni sustavi sa sposobnošću poboljšanja bioraspoloživosti lijekova slabo topljivih u vodi i organskim otapalima. U svrhu povećanja topljivosti diklofenaka (ljekovite tvari koja je slabo vodotopljiva, a uzrokuje i gastrointestinalnu toksičnost) pripravljeni su i evaluirani njegovi farmakosomi (fosfolipidni kompleksi). Diklofenak je kompleksiran s fosfatidilkolinom (80 \%) u ekvimolarnom omje$\mathrm{ru}, \mathrm{u}$ prisutnosti diklormetana, konvencionalnom metodom evaporacije. Tako pripravljenim farmakosomima ispitivana je topljivost, sadržaj ljekovite tvari, morfologija površine (pomoću pretražne elektronske mikroskopije), ponašanje pri prijelazu faza (pomoću diferencijalne pretražne kalorimetrije), kristaliničnost (rendgenskom analizom praha) i in 
vitro oslobađanje. Farmakosomi diklofenaka su nepravilnog oblika ili u obliku diska te imaju neravnu površinu u SEM-u. Sadržaj ljekovite tvari je 96,2 $\pm 1,1 \%$. DSC termogrami i XRPD podaci potvrdili su nastajanje fosfolipidnog kompleksa. Topljivost u vodi dobivenih kompleksa bila je 22,1 $\mu \mathrm{g} \mathrm{mL}-1$, a topljivost samog diklofenaka $10,5 \mu \mathrm{g} \mathrm{mL}-1$. Postignuto poboljšanje topljivosti može imati za posljedicu povećano oslobađanje i manju gastrointestinalnu toksičnost. Tijekom 10 h iz farmakosoma se oslobodilo 87,8 \%, a iz slobodnog diklofenaka samo 60,4\% ljekovite tvari.

Ključne riječi: diklofenak, topljivost, farmakosomi, fosfolipid kompleks

Department of Pharmaceutical Sciences H. N. B. Garhwal University, Srinagar Garhwal, India

Department of Chemistry H.N.B. Garhwal University, Srinagar Garhwal, India 